УДК $621.59(075.8)$

Г.К. Лавренченко, доктор техн. наук

Восточноевропейская ассоциация производителей технических газов «СИГМА», а/я 188, г. Одесса, Украина, 65026

e-mail: uasigma@mail.ru

ORCID: http://orcid.org/0000-0002-8239-7587

\title{
СОСТОЯНИЕ И ПЕРСПЕКТИВЫ РАЗВИТИЯ КИСАОРОАНОГО И КРИОГЕННОГО МАШИНОСТРОЕНИЯ
}

\begin{abstract}
На научно-производственной базе обновленного Криогенмаша и при его непосредственном участии в период 28 сентября - 2 октября 2015 года совместно с Ассоциацией «СИГМА» был проведён международный семинар по теме «Состояние и перспективы развития кислородного и криогенного машиностроения». Он был приурочен $к$ значимому событию - введению в эксплуатацию Криогенмашем построенного и оснащённого современным оборудованием многономенклатурного корпуса и созданию новых научных лабораторий. Семинар собрал более 100 специалистов из десяти государств. В работе семинара приняли участие изготовители и потребители разнообразного криогенного оборудования, в том числе и воздухоразделительных установок. Проявили интерес к семинару и компании, занимающиеся газовым бизнесом на рынке технических газов. На семинаре были заслушаны 30 докладов, в которых приведены характеристики состояния и перспектив развития научно-исследовательских и конструкторско-технологических работ по проблемным вопросам состоявшегося семинара. Рассматривается содержание выступлений, из которых делается вывод о наличии ряда перспективных результатов, которые будут способствовать дальнейшему совершенствованию криогенных систем, например, для производства сжиженного природного газа и продуктов разделения воздуха.

Ключевые слова: Криогенная техника. Воздухоразделительная установка (ВРУ). Продукты разделения воздуха. Сжиженный природный газ (СПГ). Редкие газы. Теплоизоляция. Ёмкости для жидких криопродуктов. Жидкостнопаровая турбина. Транспортировка криопродуктов. Рынок технических газов.
\end{abstract}

\section{BBEAEHИE}

В г. Балашихе (Московская область) 28 сентября - 2 октября 2015 г. на базе ПАО «Криогенмаш» и при непосредственном участии этой компании и всемерном её содействии был проведён международный семинар по актуальной теме «Состояние и перспективы развития кислородного и криогенного машиностроения». Его организаторами явились Криогенмаш и Восточноевропейская ассоциация производителей технических газов «СИГМА».

Программа семинара включала в себя два блока докладов. Первый из них содержал доклады, объединённые проблемой повышения эффективности и безопасности производств продуктов разделения воздуха. Эта проблема соответствует тематической направленности ежегодно организуемых подобных международных семинаров. Данный семинар, проведённый в Балашихе, являлся, таким образом, уже шестнадцатым в общем графике мероприятий Ассоциации «СИГМА».

Второй блок докладов должен был охарактеризовать достижения Криогенмаша. В нём планировалось заслушать и обсудить выступления, посвященные ана- лизу рынка технических газов; опыту создания и эксплуатации производств продуктов разделения воздуха, сооруженных Криогенмашем для реализации on-siteпроектов; рассмотрению основных направлений перспективной деятельности предприятия: переработка природного и попутного газов; создание эффективного СПГ-оборудования различной тоннажности, участие в проектах ИТЕР (International Thermonuclear Experimental Reactor) и «Ангара».

Девиз этого блока докладов, - «Криогенмаш»: реализуемые и перспективные инновационные проекты», — лучшим образом даёт представление об их высоком уровне.

В работе семинара приняли участие около 100 специалистов из различных компаний РФ, Украины, Италии, Германии, Люксембурга, Новой Зеландии, США, Франции, Чешской республики и Швейцарии.

Как известно [1], в этом году произошло очень важное событие. На территории Криогенмаша без остановки основного производства построен, введён в эксплуатацию и начал функционировать современный научно-производственный комплекс (рисунки 1 и 2). На тщательную подготовку к углублённой модерниза- 